\title{
Serum corticosterone concentrations in reproductively mature and inhibited deermice (Peromyscus maniculatus bairdii)*
}

\author{
Kuo-Li P. Sung†, E. L. Bradley* and C. R. Terman* \\ Laboratory of Endocrinology and Population Ecology, Department of Biology, \\ College of William and Mary, Williamsburg, Virginia 23185, U.S.A.
}

\begin{abstract}
Summary. Serum corticosterone concentrations were measured to see if there was any correlation between adrenal activity and reproductive inhibition. Males and females from two growing and one stable (asymptotic) population had significantly smaller reproductive organs (seminal vesicles, testes, uteri, ovaries) than controls. The weights of the adrenal glands of population mice were smaller, often significantly so, than those of controls, but the mean serum corticosterone concentrations were higher than those of control mice for the two growing populations and significantly higher for the asymptotic population. These data suggest that adrenal function may be associated with the reproductively inhibited condition, but not in a direct or dose-response fashion and that adrenal hyperfunction in this species may not be reflected by adrenal hypertrophy.
\end{abstract}

\section{Introduction}

Early work to define the physiological basis of the regulation of size of laboratory populations of rodents focused on measures of adrenal hypertrophy, reproductive organ atrophy, decreased litter survival and diminished pregnancy and birth rates (Southwick, 1955; Christian, 1956, 1961, 1963, 1967; Louch, 1956; Southwick \& Bland, 1959; Thiessen \& Rodgers, 1961; Bronson \& Eleftheriou, 1963; Terman, 1969). It was proposed that ACTH was responsible for the observed adrenal hypertrophy and reproductive inhibition, either through a direct inhibition of gonadotrophin secretion or indirectly through increased adrenocortical steroid production (Christian, 1963; Christian \& Davis, 1964). Support for this interpretation was derived primarily from the correlation of adrenal hypertrophy with increased population density in many of the species studied (Christian, 1971a, b) and the ability of high doses of ACTH to prevent sexual maturation of prepubertal female mice ( $\mathrm{Mus} \mathrm{muscu-}$ lus) (Christian, 1964).

Long-term injections of high doses of ACTH to deermice inhibited sexual maturation of immature animals and initiated reproductive regression in adults of both sexes (Christian, 1971a; Pasley \& Christian, 1972), and Ogle (1974a, b) has shown that high doses of ACTH interfere with ovarian function and pregnancy in female Peromyscus in a pattern similar to that expected when LH secretion is deficient. Adrenal hypertrophy has not, however, been detected in deermice (Peromyscus spp.) even though drastic inhibition of reproduction has been recorded in laboratory populations (Terman, 1969, 1973a, b; Christian, 1971a, b; Albertson, Bradley \& Terman, 1975). Hypertrophy and hyperfunction are not necessarily correlated (Eechaute, Demiester, Lacroix \& Leusen, 1962; Andrew, 1968), and the present study was undertaken to determine the serum concentrations of corticosterone in deermice from laboratory populations in which reproduction was inhibited.

\footnotetext{
* Reprint requests to Dr E. L. Bradley or Dr C. R. Terman, Department of Biology, College of William and Mary, Williamsburg, Virginia 23185, U.S.A.

† Present address: Department of Physiology, College of Physicians \& Surgeons, Columbia University, New York, New York 10032, U.S..A
} 


\section{Materials and Methods}

\section{Animals}

Twenty pairs of control prairie deermice (Peromyscus maniculatus) were used. Adult males were paired with non-sibling females of approximately the same age (79-113 days) in cages $(12 \times 26 \times 14$ $\mathrm{cm}$ ) which allowed reception of visual, olfactory and auditory cues but prevented contact by means of a partition made of two layers of $0.6 \mathrm{~cm}$ hardware cloth $2 \mathrm{~cm}$ apart. The age at death was between 230 and 270 days.

Three experimental populations were founded by 4 pairs of deermice from 8 different litters (60-100 days of age), the female of each pair being pregnant. The first young born to each female were removed within $24 \mathrm{~h}$ to eliminate the possibility of variable prenatal experience. All subsequent litters remained as part of that population. The populations were maintained for approximately 300 days before sampling (see below) in corrugated, galvanized-steel enclosures (diameter $48.3 \mathrm{~cm}$; floor area $1829.2 \mathrm{~cm}^{2}$ ) provided with wood shavings, tap water and four plastic nest boxes. Population 3 had not increased in size for 167 days and comprised 79 animals ( 47 females and 32 males). Populations 1 and 2 were still growing when sampled: Population 2 contained 48 animals older than 21 days of age ( 16 females and 32 males) while Population 1 contained 32 animals ( 14 females and 18 males) older than 21 days. Such variability among populations has been noted previously (Terman, 1973b, 1976).

The control and experimental population animals were maintained in the same room $\left(5.5 \mathrm{~m}^{2}\right)$ which was brightly lit by four 40 -W fluorescent bulbs from 08.00 to $19.30 \mathrm{~h}$, and dimly illuminated with four 15-W incandescent bulbs from 20.00 to $07.30 \mathrm{~h}$. Between each light change there was a 30 min period of darkness. Room temperatures were kept within $21-30^{\circ} \mathrm{C}$. There were $5-10$ air changes $/ \mathrm{h}$ in the animal room. Food (D \& G Laboratories, Maryland) and water were always available. All animals were identified by toe clipping and examined twice weekly for reproductive condition.

\section{Blood and organ collection}

Deermice that were $>90$ and $<350$ days old were removed as encountered at the rate of 1 male or female per day from each population. Only females known to be nulliparous were sampled.

Between 14.00 and $15.30 \mathrm{~h}$ (i.e. $4-5 \frac{1}{2} \mathrm{~h}$ before the onset of the dark/dim period), the selected animal was rapidly anaesthetized with ether. Blood was obtained by venepuncture from the vena cava at the level of the renal vein within $3 \mathrm{~min}$ from the time of the first contact with the animal. The blood was allowed to clot and then centrifuged at $6800 \mathrm{~g}$ for $20 \mathrm{~min}$; the serum was stored in plastic tubes at below $-20^{\circ} \mathrm{C}$ until assayed. The whole animal was placed in a $10 \%$ formalin solution. Later, testes, seminal vesicles and adrenals were removed from all males, and adrenals, ovaries and uteri plus oviducts from all females. All uteri were checked for the absence of embryos or placental scars. The organs were cleaned of extraneous tissue, blotted, and weighed twice to the nearest $0.1 \mathrm{mg}$ on an electrobalance (Cahn) interfaced with a Wang 700B programmable calculator.

\section{Corticosterone assay}

This was a modification of the competitive protein-binding of Murphy (1967). Heparinized dog plasma $(0.6 \mathrm{ml})$ was diluted to $50 \mathrm{ml}$ with distilled water and dialysed with Tyrode's Ringer solution. The diluted plasma was then mixed with $0.6 \mu \mathrm{Ci}\left[1,2-{ }^{3} \mathrm{H}\right]$ corticosterone (sp. act. $49 \cdot 5 \mathrm{Ci} / \mathrm{mmol}$ : New England Nuclear, Boston, Mass.) and used directly as the corticosteroid-binding globulin (CBG). Duplicate $0.1 \mathrm{ml}$ serum samples were equilibrated with known amounts (about $2000 \mathrm{~d} / \mathrm{min}$ ) of authentic $\left[1,2-{ }^{3} \mathrm{H}\right]$ corticosterone, checked for purity by TLC, to give recovery estimates for each sample. The samples were extracted with $3 \mathrm{ml}$ methylene chloride and chromatographed on silica plates (60 F-254: E.M. Laboratories, Inc., Elmsford, N.Y.) and the gel developed with chloroform: ethanol $(95: 5 \mathrm{v} / \mathrm{v})$. The plates were washed by ascending chromatography with chloroform: ethanol $(95: 5 \mathrm{v} / \mathrm{v})$ before use. Corticosterone markers were located under u.v. light and the samples were 
scraped from the plate into individual Pasteur pipettes plugged with glass-wool before elution with ethanol:methylene chloride $(2: 1 \mathrm{v} / \mathrm{v})$ and evaporation to dryness in the reaction tube. The dried extract was redissolved with $3.0 \mathrm{ml}$ ethanol :methylene chloride $(2: 1 \mathrm{v} / \mathrm{v})$ and allowed to equilibrate for $5 \mathrm{~h}$ at $6^{\circ} \mathrm{C}$. For an estimate of recovery, $500 \mu \mathrm{l}$ of the total sample was taken from each tube and the rest evaporated to dryness. One $\mathrm{ml} \mathrm{CBG}$ solution was equilibrated with each sample or standard by continuous shaking for $10 \mathrm{~h}$ at $6^{\circ} \mathrm{C}$. Florisil (60-100 mesh: J. T. Baker, Phillipsburg, N.J.) was added to each tube with a calibrated spoon. The tubes were shaken for $12 \mathrm{~h}$ and then allowed to settle for $2 \mathrm{~h}$. A $500 \mu \mathrm{l}$ aliquot of the supernate of each sample was added to $10 \mathrm{ml}$ Bray's solution and the vials were counted for tritium activity in a Nuclear Chicago liquid scintillation counter (Series 720). A standard curve was constructed from the values obtained from duplicate corticosterone (crystalline: Schwartz-Hann, Orangeburg, New York) standards $(0,0 \cdot 25,0 \cdot 5,0 \cdot 75,1 \cdot 0,2.0$ and 5.0 $\mathrm{ng}$ ) and the amount of corticosterone in the samples was read directly from the standard curve.

The linear regression equations for the two standard curves used gave slopes of $r=0.998$ and $r=$ 0.953 which were not significantly different. The slopes of plots of corticosterone measured in rat and deermouse sera in serial dilutions $(200,100,50,25 \mu \mathrm{l})$ run in duplicate were also not significantly different. The mean recovery value for $0 \cdot 25,0.5,0.75$ and $1.0 \mathrm{ng}$ authentic corticosterone, assayed in triplicate and corrected for procedural losses, was $96.3 \pm 5.63 \%$. The sensitivity of the assay was at least $0 \cdot 25 \mathrm{ng}$.

\section{Statistical analysis}

Bartlett's test revealed significant heterogeneity of variance between mean values for body weight and age in males and females, and for adrenal, uterus and ovary weights in females: comparisons of values involving these parameters were therefore made using the non-parametric Mann-Whitney $\mathbf{U}$ test. There was no heterogeneity of variance for the other parameters and values were compared using the Student's $t$ test. A probability level of $P=\mathbf{0 . 0 5}$ or less was considered significant.

\section{Results}

No significant differences were observed between control males and control females with respect to age, body weight, absolute or relative adrenal weight or serum corticosterone concentration (Tables 1 and 2). Similarly, there were no significant differences between males and females in Population 3 with respect to age, body weight, relative adrenal weight or serum corticosterone, but the absolute adrenal weights of the females were less $(P<0.05)$ than those of the males.

Only females within Population 3 could be compared with the controls (see Table 1) because there were only 2 and 3 females in Populations 2 and 1 , respectively, that were within the age limit previously established for sampling and also nulliparous. There were 10 males within the appropriate age range in each of the populations and comparisons were made between the several populations and the controls (Table 2).

Table 1. Mean \pm S.E.M. age, body and organ weights and serum corticosterone concentrations of control female deermice and those from Population 3

\begin{tabular}{|c|c|c|c|c|c|c|c|}
\hline & \multirow[b]{2}{*}{$\begin{array}{c}\text { Age } \\
\text { (days) }\end{array}$} & \multirow[b]{2}{*}{$\begin{array}{l}\text { Body wt } \\
\text { (g) }\end{array}$} & \multicolumn{2}{|c|}{ Adrenal wt } & \multirow[b]{2}{*}{$\begin{array}{l}\text { Ovary wt } \\
\text { (mg) }\end{array}$} & \multirow[b]{2}{*}{$\begin{array}{l}\text { Uterus wt } \\
\text { (mg) }\end{array}$} & \multirow{2}{*}{$\begin{array}{l}\text { Serum } \\
\text { corticosterone } \\
(\mu \mathrm{g} / 100 \mathrm{ml})\end{array}$} \\
\hline & & & $\begin{array}{l}\text { Absolute } \\
\text { (mg) }\end{array}$ & $\begin{array}{c}\text { Relative } \\
\text { (mg/g body wt) }\end{array}$ & & & \\
\hline Control & 253.2 & $20 \cdot 12$ & $2 \cdot 52$ & 0.129 & $21 \cdot 57$ & $51 \cdot 02$ & $6 \cdot 14$ \\
\hline$(N=20)$ & \pm 2.49 & \pm 0.94 & \pm 0.13 & \pm 0.008 & \pm 3.67 & \pm 4.99 & \pm 0.90 \\
\hline Population 3 & $294 \cdot 3$ & $\overline{15} \cdot 28$ & 1.85 & 0.122 & $\overline{7} \cdot 10$ & $10 \cdot 33$ & $13 \cdot 17$ \\
\hline$(N=19)$ & $\pm 10 \cdot 11 \ddagger$ & $\pm 1.42 \dagger$ & $\pm 0.08 \ddagger$ & \pm 0.007 & $\pm 0.69^{*}$ & $\pm 1.92 \ddagger$ & $\pm 1.87 \dagger$ \\
\hline
\end{tabular}

Significantly different from control value at $* P<0.01 ; \dagger P<0.02 ; \ddagger P<0.001$. 
Table 2. Mean \pm S.E.M. age, body and organ weights and serum corticosterone concentrations of control and population male deermice

\begin{tabular}{|c|c|c|c|c|c|c|c|}
\hline & \multirow[b]{2}{*}{$\begin{array}{c}\text { Age } \\
\text { (days) }\end{array}$} & \multirow[b]{2}{*}{$\begin{array}{c}\text { Body wt } \\
\text { (g) }\end{array}$} & \multicolumn{2}{|c|}{ Adrenal wt } & \multirow[b]{2}{*}{$\begin{array}{l}\text { Testis wt } \\
\text { (mg) }\end{array}$} & \multirow{2}{*}{$\begin{array}{l}\text { Seminal } \\
\text { vesicle wt } \\
\text { (mg) }\end{array}$} & \multirow{2}{*}{$\begin{array}{c}\text { Serum } \\
\text { corticosterone } \\
(\mu \mathrm{g} / 100 \mathrm{ml})\end{array}$} \\
\hline & & & $\begin{array}{c}\text { Absolute } \\
\text { (mg) }\end{array}$ & $\begin{array}{c}\text { Relative } \\
\text { (mg/g body wt) }\end{array}$ & & & \\
\hline $\begin{array}{l}\text { Control } \\
(N=20) \\
\text { Population } 3\end{array}$ & $\begin{array}{l}240 \cdot 0 \\
\pm 12.85^{2}-\pi\end{array}$ & $\begin{array}{l}20 \cdot 1 \\
\pm 0 \cdot 60^{n, b}\end{array}$ & $\begin{array}{r}2 \cdot 72 \\
\pm 0 \cdot 17^{a}\end{array}$ & $\begin{array}{r}0.136 \\
\pm 0.010\end{array}$ & $\begin{array}{l}377 \cdot 35 \\
\pm 15 \cdot 33^{\mathrm{a}, \mathrm{b}, \mathrm{c}}\end{array}$ & $\begin{array}{l}210 \cdot 90 \\
\pm 15 \cdot 17^{\mathrm{a}, \mathrm{b}, \mathrm{c}}\end{array}$ & $\begin{array}{c}5 \cdot 36 \\
\pm 1 \cdot 12^{\mathrm{a}} \dagger\end{array}$ \\
\hline$(\mathrm{N}=19)$ & $\begin{array}{l}277.9 \\
\pm 20.97^{b}+\end{array}$ & $\begin{array}{l}20 \cdot 3 \\
\pm 2 \cdot 11\end{array}$ & $\begin{array}{r}2 \cdot 20 \\
\pm 0 \cdot 13\end{array}$ & $\begin{array}{r}0.117 \\
\pm 0.013\end{array}$ & $\begin{array}{c}209.88 \\
\pm 42.69^{\mathrm{a}} \S\end{array}$ & $\begin{array}{c}71.43 \\
\pm 21.38^{2} \S\end{array}$ & $\begin{array}{l}13 \cdot 48 \\
\pm 2 \cdot 29^{a, b, c}\end{array}$ \\
\hline $\begin{array}{l}\text { Population } 2 \\
(\mathrm{~N}=10)\end{array}$ & $\begin{array}{l}203 \cdot 6 \\
\pm 30 \cdot 22^{\mathrm{c}} 8\end{array}$ & $\begin{array}{l}15 \cdot 5 \\
\pm 0.49^{n} \dagger\end{array}$ & $\begin{array}{c}2.04 \\
\pm 0.09^{ \pm} \ddagger\end{array}$ & $\begin{array}{r}0.135 \\
\pm 0.007\end{array}$ & $\begin{array}{l}188 \cdot 10 \\
\pm 18.71^{b} \S\end{array}$ & $\begin{array}{c}88 \cdot 12 \\
\pm 21 \cdot 91^{\mathrm{b}} \S\end{array}$ & $\begin{array}{c}5 \cdot 51 \\
\pm 1 \cdot 12^{b *}\end{array}$ \\
\hline $\begin{array}{l}\text { Population } 1 \\
(\mathrm{~N}=10)\end{array}$ & $\begin{array}{l}119 \cdot 9 \\
\pm 6 \cdot 23^{a, b, c}\end{array}$ & $\begin{array}{c}16.6 \\
\pm 0.85^{b} \uparrow\end{array}$ & $\begin{array}{r}2.27 \\
\pm 0 \cdot 18\end{array}$ & $\begin{array}{r}0 \cdot 140 \\
\pm 0 \cdot 008\end{array}$ & $\begin{array}{l}187 \cdot 40 \\
\pm 21.84^{c} \S\end{array}$ & $\begin{array}{c}56.03 \\
\pm 14.54^{\mathrm{c}}\end{array}$ & $\begin{array}{c}7 \cdot 29 \\
\pm 1 \cdot 47^{c} \ddagger\end{array}$ \\
\hline
\end{tabular}

Within columns, means with the same superscript are significantly different: ${ }^{*} P<0.02 ; \nmid P<0.01 ; \ddagger P<0.05$; $\S P<0.002 ; \pi P<0.001$.

No significant correlations could be demonstrated for either sex in control or population animals, between adrenal and gonadal weight or serum corticosterone concentration and adrenal weight, age, body weight or gonadal weight.

\section{Discussion}

It is of interest to note that although no significant differences were demonstrated between sexually mature (230-270 days old) control males and females in this study with respect to body weight and adrenal weight, it was previously found that males had larger body weights and smaller adrenals than females (Terman, 1969), perhaps because the animals in the earlier study were younger (mean age 123 days for females, 155 days for males) and the caging conditions were different.

An attempt was made to use control animals with a mean age approximating the mean age of all of the population animals. Because the age range in controls was restricted (230-270 days) compared with the great range of ages of population animals (90-350 days), the variance between the groups was significant and significant mean age differences were demonstrated in some nonparametric comparisons. However, we attach little physiological significance to these differences because the population animals were all older than the minimum age for reproduction and were well under the 750-day age at which deermice have been previously shown to be reproductively active (Terman, 1973a, 1976). We are therefore confident that the population animals were neither too old nor too young to have been reproductively functional if they had been removed from the population context.

The nulliparous females withdrawn from Population 3, which was reproductively inhibited, had significantly lighter adrenal, ovarian and uterine weights than the controls, but more than twice the mean serum corticosterone concentration. A similar finding was noted for the males from Population 3.

We fully recognize the labile nature of plasma corticosterone concentration with respect to changing environmental stimuli, but we feel that the rapid sampling of each animal without any prior disturbance permitted accurate estimation of the resting value of corticosterone. Further, because control animals were sampled in the same way as the population animals, the comparison was valid for any effects of sampling. 
Blood corticosterone levels have been shown to be significantly elevated during acute and chronic stress of rats and some other laboratory animals (Friedman \& Ader, 1968; Ganjam, Campbell \& Murphy, 1972; Zimmerman, Smyrl \& Critchlow, 1972; Cook, Kendall, Greer \& Kramer, 1973; Dallman \& Jones, 1973; Riegle, 1974; Barlow, Morrison \& Sullivan, 1975), and an increase in plasma ACTH precedes the corticosterone elevation (Cook et al., 1973). If it is assumed that in Peromyscus corticosterone concentration reflects ACTH concentration, then the possibility is very strong that there were high titres of ACTH in the plasma of animals born into the reproductively inhibited Population 3.

The reason for the difference in serum corticosterone levels of the males in the three populations is not clear. Population 3 had ceased to grow approximately 6 months before sampling, unlike the other two populations which were still growing and contained fewer animals. Whether or not cessation of growth and density are responsible for these differences remains to be demonstrated. Previous studies and the present findings show that population density is not reflected in differential body weights, adrenal, or reproductive organ weights (Terman, 1973b).

Because of the lack of significant correlations between adrenal and gonadal weights, and between adrenal function (in terms of serum corticosterone) and the weights of the adrenals or gonads, corticosterone concentration per se cannot be directly related to the weight of the gonads within any population or control group. In these populations, therefore, adrenal corticoid hyperfunction appeared to be associated with reproductive inhibition but not in a direct or dose-response relationship.

The research was supported in part by a grant to E.L.B. and C.R.T. from the National Institutes of Health, HD 08906.

\section{References}

Albertson, B.D., Bradley, E.L. \& Terman, C.R. (1975) Plasma progesterone concentrations in prairie deermice (Peromyscus maniculatus bairdii) from experimental laboratory populations. $J$. Reprod. Fert. 42, 407-417.

ANDREw, R.V. (1968) Effects of exogenous ACTH on precursor utilization in lessening adrenal steroidogenesis. Endocrinology 83, 1387-1389.

Barlow, S.M., Morrison, P.J. \& Sullivan, F.M. (1975) Effects of acute and chronic stress on plasma corticosterone levels in the pregnant and nonpregnant mouse. J. Endocr. 66, 93-99.

Bronson, F.H. \& Elefrheriou, B.E. (1963) Adrenal responses to crowding in Peromyscus and C57BL/10J mice. Physiol. Zool.36, 161-166.

Christian, J.J. (1956) Adrenal and reproductive responses to population size in mice from freely growing populations. Ecology 37, 258-273.

Christian, J.J. (1961) Phenomena associated with population density. Proc. natn. Acad. Sci. U.S.A. 47, $428-449$.

Christian, J.J. (1963) Endocrine adaptive mechanisms and the physiological regulation of population growth. In Physiological Mammalogy, pp. 189-353. Eds W. V. Mayer \& R. G. VanGelder. Academic Press, New York.

Christian, J.J. (1964) Effect of chronic ACTH treatment on maturation of intact female mice. Endocrinology 74, 669-679.

Christian, J.J. (1967) Effect of population size on the adrenal glands and reproductive organs of male mice in populations of fixed size. In Hormones and Behavior, pp. 23-26. Ed R. E. Whalen. VanNostrand Co., Princeton.

Christian, J.J. (1971a) Population density and reproductive efficiency. Biol. Reprod. 4, 248-294.

Christian, J.J. (1971b) Population density and fertility in mammals. In The Action of Hormones: Genes to Population, pp. 471-499. Ed. P. Foa. C. C. Thomas, Springfield, Illinois.

Christian, J.J. \& Davis, D.E. (1964) Endocrines, behavior and population. Science, N.Y. 146, 15501560.

COOK, D.M., Kendall, J.W., Greer, M.A. \& Kramer, R.M. (1973) The effect of acute or chronic ether stress on plasma ACTH concentration in the rat. Endocrinology 93, 1019-1024.

Dallman, M.F. \& Jones, M.T. (1973) Corticosteroid feedback control of ACTH secretion: effect of stress-induced corticosterone secretion on subsequent stress responses in the rat. Endocrinology 92 , 1367-1375.

Eechaute, W., Demiester, G., Lacroix, E. \& Leusen, I. (1962) The adrenal cortex activity during experimental renal hypertension in rats. Arch. Int. Pharmacodyn. 136, 161-173.

Friedman, S.B. \& ADER, R. (1968) Adrenocortical response to novelty and noxious stimulation. Neuroendocrinology 2, 209-212.

Ganjam, V.K., CAMPBell, A.L. \& MURPHY, B.E.P. (1972) Changing patterns of circulating corticosteroids in rabbits following prolonged treatment with ACTH. Endocrinology 91, 607-611. 
LoucH, C.D. (1956) Adrenocortical activity in relation to density and dynamics of three confined populations of Microtus pennsylvanicus. Ecology 37, 701713.

Murphy, B.E.P. (1967) Some studies of the proteinbinding of steroids and their application to the routine micro- and ultramicromeasurement of various steroids in body fluids by competitive protein binding radioassay. J. clin. Endocr. Metab. 27,973-990.

OGLE, T.F. (1974a) Effects of ACTH on organelle interrelationships in the corpus luteum of the pregnant deermouse. Cell Tiss. Res. 153, 195-209.

OGLE, T.F. (1974b) Effects of ACTH on ovarian histochemistry and maintenance of pregnancy in deermice. Biol. Reprod. 11, 288-296.

Pasley, J.N. \& Christian, J.J. (1972) The effect of ACTH, group caging, and adrenalectomy in Pero. myscus leucopus with emphasis on suppression of reproductive function.Proc. Soc. exp. Biol. Med. 139, 921-925.

Riegle, G.D. (1974) Chronic stress effects on adrenocortical responsiveness in young and aged rats. Neuroendocrinology 11, 1-10.

SoutHwick, C.H. (1955) The population dynamics of confined house mice supplied with unlimited food. Ecology 36, 212-225.
Southwick, C.H. \& Bland, V.P. (1959) Effect of population density on adrenal glands and reproductive organs of CFW mice. Am. J. Physiol. 197, 111114.

TERMAN, C.R. (1969) Weights of selected organs of deermice (Peromyscus maniculatus bairdii) from asymptotic laboratory populations. J. Mammal. 50, 311-320.

TeRman, C.R. (1973a) Recovery of reproductive function by prairie deermice from asymptotic populations. Anim. Behav. 21, 443-448.

Terman, C.R. (1973b) Reproductive inhibition in asymptotic populations of prairie deermice. $J$. Reprod. Fert., Suppl. 19,455-461.

Terman, C.R. (1976) Laboratory studies of population regulation in prairie deermice. Proc. Centennial Symp. Sci.\& Res., Phila. Zoo. Soc., pp. 199-220. Ed. R. L. Snyder. Hills Division Riviana Foods, Topeka, Kansas.

ThIessen, D.D. \& Rodgers, D.A. (1961) Population density and endocrine function. Psychol. Bull. 58, 441-451.

Zimmerman, E., Smyri, R. \& Critchlow, V. (1972) Suppression of pituitary-adrenal response to stress with physiological plasma levels of corticosterone in the female rat. Neuroendocrinology 10, 246256.

Received 15 June 1976 